Filip KUKIC*,

Strategic management and performance improvement department, Sport activities section, Abu Dhabi Police

Prof. Milivoj DOPSAJ, PhD

Faculty of Sport and Physical Education, Belgrade

doi:10.5937/bezbednost1702005K

UDK: 351.74(536.2):796.012.1

Originalni naučni rad

Primljen: 12. 6. 2017. godine

Datum prihvatanja: 26. 10. 2017. godine

\title{
Factorial Analysis Of Body Composition In Abu Dhabi Policemen ${ }^{1}$
}

Abstract: The aim of this study was to define the factors that influence the structure of the body composition in Abu Dhabi police workforce. Body composition of 120 randomly-selected different-age male officers was measured during October and November 2016 in Sports activities section of Abu Dhabi Police. Characteristics of the sample were:

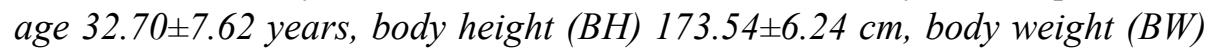
$80.55 \pm 11.36 \mathrm{~kg}$ and body mass index (BMI) $26.76 \pm 3.60 \mathrm{~kg} / \mathrm{m} 2$. Eleven variables were statistically evaluated using factorial analysis of variance: percentage of body fat (PBF), percentage of skeletal muscle mass (PSMM), percentage of protein mass (PPM), volume-independent visceral fat area (VFA/kg), body fat mass index (BFMI), skeletal muscle mass index (SMMI), protein mass index (PMI), fat-free mass index (FFMI), visceral fat area index (VFAI), protein-fat index (PFI), and index of hypokinezia (IH). KMO and Bartlett's test showed very good sampling adequacy of 0.661 with significance level lower than 0.001. Principal component analysis showed high cumulative values. Accordingly, the proportion of variance of each

*filip.kukic@gmail.com

** Prof.Dr Milivoj Dopsaj, milivoj.dopsaj@gmail.com

1 This research is part of the project Effects of applied Physical activity on locomotor, metabolic, psychosocial and educational status of the population of the Republic of Serbia, under number III47015, which is financed by Ministry of Education and Science of Republic of Serbia - Cycle of Projects 2011-2016.

БЕЗБЕДНОСТ 2/2017 
variable that can be explained by factor is very high. Factor loading showed the three most important factors that explained 97.004: I - INACTIVITY AND NUTRITION, II - PHYSICAL ACTIVITY AND EXERCISE, and III SEDENTARY LIFESTYLE. For the purposes of monitoring of inactivity level along with eating habits, two index variables could be followed - PPM and $P B F$; For monitoring the quality of the physical activity and the planned exercise program - PMI and FFMI; for the influence of lifestyle on body composition - VFA/kg and VFAI could be followed.

Keywords: exercise, inactivity, sedentary, lifestyle, health

\section{Introduction}

Police personnel includes a wide range of different professions depending on department of employment. Some of their responsibilities mainly consist of long stressful sitting hours like IT security, salary section, economy department, traffic department and many more. On the other hand, some responsibilities are psycho-physically very demanding like protecting sports events, quick and urgent response, counter-terrorist unit response, firefighter unit response, etc. Generally, police job is to maintain social safety and security through interpersonal contact and/or through involving basic and special physical abilities (Kukic and Dopsaj, 2016; Dopsaj and Dimitrijevic, 2013; Vuckovic et al., 2011; Sorensen et al., 2000; Dimitrijevic et al., 2013; Violanti et al., 2006). There are a lot of officers facing difficult schedules, long working hours, terrible crime scenes, etc. and all these job-related stress situations might lead to inadequate sleep, metabolic disorders, cardiac irregularities and some other health issues ( $\mathrm{Gu}$ et al., 2012). Therefore, strategic management and performance improvement should use professional expert system that would contribute to precision of selection processes as well as processes of surveillance and monitoring of employees' health and physical readiness for certain duties.

One of the first and the most sensitive factors that indicate changes in health is the body composition status. Historically, the body composition studies have been conducted over a span of 100 years and during this time they developed from the original two-compartment model to the modern fiveand multi-compartment model. The influence of new technologies and need 
for better understanding of the human body elevated body composition studies to a completely new level where instead of seeing the human body composition only as fat mass and fat-free mass, human body composition is considered more holistically as fat mass, muscle mass, protein mass, bones, minerals, intracellular water, extracellular water, visceral fat area, etc. (Wang et al., 1992; Ellis, 2000; Dopsaj and Dimitrijevic, 2013; Djordjevic-Nikic et al., 2013).

Body composition has been frequently investigated over the years because of its biological meaning (Wang et al., 1992; Ellis, 2000). Human body consists of different tissues which in turn consist of cells and those cells are composed of atoms. Moreover, human body is a live organism because all those compartments connect and contact between each other. This means that those compartments also influence each other and the origin of the relationship and constancy of that relationship are fundamental in body composition research. It allows better insight in biology of the human body composition and indirectly better control of human health. Wang et al. (2004) stated "Nutritional status, physical activity level, and disease state alter body cell mass, which in turn serves as a biomarker of these processes" (Wang et al., 1992; Wang et al., 2000; Wang et al., 2004; Ellis, 2000; Dopsaj and Dimitrijevic, 2013; Kyle et al., 2003).

Different studies showed that, ethnicity, social status, climate conditions, moving patterns, geographical area, and habitual behavior might have the influence on the body size, bone density, tissue selection and morphology. Habitual behavioral mobility is one of the most repetitive aspect of loading on skeleton and logically, different climate conditions over a thousand-year period will lead to different genetic adaptations (Stock, 2006; Weaver and Steudel-Numbers, 2005; Bogin and Rios, 2003; Ruff, 2000; Adler et al., 2000; Katzmarzyk and Leonard, 1998; Cardel et al., 2016). People from warm climate places are usually with more narrow bodies and long limbs due to thermoregulation while people from cold places are usually more with wide bodies and shorter limbs to retain heat (Kasabova and Holliday, 2015; Stock, 2006; Weaver and Steudel-Numbers, 2005; Katzmarzyk and Leonard, 1998). Katzmarzyk and Leonard (1998) showed significant relationship between body size area relative to body mass and mean annual temperature. They explained it as an adaptive response to thermal stress through climate's influence on food availability. Consequently, climate-dependent nutritional variations are important in understanding the 
association between body mass and mean annual temperature on a regional basis (Katzmarzyk and Leonard, 1998). Because of those variations in body volume and segmental proportions and accordingly distribution of the body mass (Kasabova and Holliday, 2015; Ruff, 2000) the measurement and estimation of the body composition may be updated with indexes that will include body volume and size independent indicators of body composition. This should provide a more precise explanation of the factors influencing the body composition. Thus, the importance of the factorial analysis of index values lies in the very nature of both the internal and external effects on variations in body morphology.

There are no studies that deal with body composition in Abu Dhabi police and accordingly scientific data are missing in terms of evaluation of this phenomenon. The aim of this study is to define the factors that influence the structure of the body composition in Abu Dhabi police workforce. For that purpose, body size and volume independent indexes will be used so the structure can be defined as independent factors. This would result in better understanding of independent impacts of different factors on population of Abu Dhabi police personnel. In this regard, the study gives initial values of different indicators of body structure but also implements a novel variable for body structure - index of hypokinezia. In the long term, this approach could provide foundations for developing the departmental exercise programs that would deal with the sources of changes in body morphology.

\section{Methods}

This study could be classified as applied non-experimental scientific research conducted by laboratory principles and using a random sample.

\section{Participants}

The sample included 120 randomly selected male officers of different age. Main characteristics of the sample were: age $32.70 \pm 7.62$ years, body height (BH) $173.54 \pm 6.24 \mathrm{~cm}$, body weight (BW) $80.55 \pm 11.36 \mathrm{~kg}$ and body mass index (BMI) $26.76 \pm 3.60 \mathrm{~kg} / \mathrm{m}^{2}$. All subjects as well as trainers that conducted measurements were informed about the aim of the study and subjects were measured only if they agreed to be the part of the study. 


\section{Measurement procedures}

Measurement procedures were conducted using multi-channel bioelectric impedance InBody 720 (Biospace Co. Ltd, Seoul, Korea) in accordance with its standard procedures. Strategic Management \& Performance Improvement Department, Sports Activity Section, Abu Dhabi police monitored data collection. Subjects were instructed to come in the morning before breakfast and fluid intake but they could come any time during the day when they were free and able to come according to their working shift. To be as accurate as possible they were instructed not to eat and drink any fluid minimum 3 hours prior to measurement.

The participants were measured in underwear, barefoot, and all metal, plastic, and magnetic accessories were removed as proposed in previous research (Kukic and Dopsaj, 2016). To measure their weight, first they positioned feet on metal spots designed for feet. After that the instruction was given to extend their posture and stand straight as when their height is measured. After the machine signaled the end of weight measurement, the participants took the handles with electrodes positioned on the lower and the upper edge of the handles. Four fingers were positioned on the lower edge and the thumb was placed on the upper edge. Hands were parallel to the body with $15-20^{\circ}$ of shoulder abduction. The participants stood steadily in this position until the sound and the instructor signaled that the measurement procedure is over.

\section{Variables}

This study includes 14 variables where 2 are basic and 12 calculated as index values. Index-values approach was applied so the body structure can be explained on tissue level, independently of body height and volume. Following variables are used:

Basic variables:

1) Body height (BH) presented in cm;

2) Body weight $(\mathbf{B W})$ presented in $\mathrm{kg}$; 
Derived variables:

1) Body mass index (BMI), presented in $\mathrm{kg} / \mathrm{m}^{2}$;

2) Percentage of body fat (PBF) presented as body fat Mass (BFM) relative to $\mathrm{BW}$, calculated as: $(\mathrm{BF} / \mathrm{BW}) * 100=\mathrm{PBF}(\%)$

3) Percentage of skeletal muscle mass (PSMM) presented as skeletal muscle mass $(\mathrm{SMM})$ relative to $\mathrm{BW}$, calculated as: $(\mathrm{SMM} / \mathrm{BW})$ * $100=$ PSMM $(\%)$

4) Percentage of protein mass (PPM) presented as protein mas (PM) relative to $\mathrm{BW}$, calculated as: $(\mathrm{PM} / \mathrm{BW}) * 100=\mathrm{PPM}(\%)$

5) Volume-independent Visceral fat area $(\mathbf{V F A} / \mathbf{k g})$ presented as a visceral fat area (VFA) relative to $\mathrm{BW}$, calculated as: VFA $\left(\mathrm{cm}^{2}\right) / \mathrm{BW}(\mathrm{kg})=\mathrm{VFA} / \mathrm{kg}\left(\mathrm{cm}^{2} / \mathrm{kg}\right)$

6) Body Fat Mass Index (BFMI) presented as body fat relative to body size, calculated as: $\mathrm{BFM} / \mathrm{BH}^{2}=\mathrm{BFMI}\left(\mathrm{kg} / \mathrm{m}^{2}\right)$

7) Skeletal Muscle Mass Index (SMMI) presented as SMM relative to body size, calculated as: $\mathrm{SMM} / \mathrm{BH}^{2}=\mathrm{SMMI}\left(\mathrm{kg} / \mathrm{m}^{2}\right)$

8) Protein Mass Index (PMI) presented as PM relative to body size, calculated as: $\mathrm{PM} / \mathrm{BH}^{2}=\mathrm{PMI}\left(\mathrm{kg} / \mathrm{m}^{2}\right)$

9) Fat-Free Mass Index (FFMI) presented as fat-free mas (FFM) relative to body size, calculated as: $\mathrm{FFM} / \mathrm{BH}^{2}=\mathrm{FFMI}\left(\mathrm{kg} / \mathrm{m}^{2}\right)$

10) Visceral Fat Area Index (VFAI) as the size-independent VFA, calculated as:

$\operatorname{VFA}\left(\mathrm{cm}^{2}\right) / \mathrm{BH}^{2}(\mathrm{~m})=\operatorname{VFAI}\left(\mathrm{cm}^{2} / \mathrm{m}^{2}\right)$

11) Protein Fat Index (PFI) presented as PM relative to BFM, calculated as:

$\mathrm{PF} / \mathrm{BFM}=\mathrm{PFI}(\mathrm{kg})$

12) Index of Hypokinezia (IH) presented as PBF relative to BMI, calculated as:

$\mathrm{PBF} / \mathrm{BMI}=\mathrm{IH}$ (index unit)

\section{Statistics}

Descriptive parametric and non-parametric statistics were calculated using Microsoft excel from Microsoft office software package (Office 365 subscription, 2016): mean, standard deviation (SD), minimum (min), maximum (max) and coefficient of variation $(\mathrm{cV})$ were calculated. All 
variables were tested for normality of distribution using skewness and kurtosis as well as non-parametric Kolmogorov-Smirnov test.

To better explain the structure of the body composition and to provide valid explanation, factorial analysis was applied. The method of Principal-Components was used for getting correlation matrix and the KMO and Bartlett's criteria was set to determine the level of significance and significant factors in accordance to the number of eigenvalues of the correlation matrix, greater or equal to one while Oblimin with Kaiser normalization was used for factor extraction. For the factorial analysis statistics software package SPSS was used (IBM, SPSS statistics, version 23).

\section{Results}

Descriptive statistics for all variables is shown in Table 1. All variables were normally distributed with skewness values ranged from 0.207 (for $\mathrm{IH}$ ) -1.512 (for PFI) and kurtosis values ranged from -0.405 (for $\mathrm{IH})-2.647$ (for PFI). Kolmogorov-Smirnov test results of significance ranged from $0.000-0.200$.

Table 1_Descriptive statistics for all variables.

\begin{tabular}{|c|c|c|c|c|}
\hline VARIABLES & MEAN \pm SD & MIN & MAX & CV (\%) \\
\hline AGE & $32.70 \pm 7.62$ & 19.00 & 54.00 & 23.3 \\
\hline BH (cm) & $173.54 \pm 6.24$ & 156.00 & 191.00 & 3.6 \\
\hline BW (kg) & $80.55 \pm 11.36$ & 53.00 & 112.40 & 14.1 \\
\hline BMI (kg/m $\mathbf{m}^{\mathbf{2}}$ & $26.76 \pm 3.60$ & 17.11 & 37.23 & 11 \\
\hline PBF (\%) & $25.31 \pm 7.40$ & 9.46 & 47.74 & $10 \%$ \\
\hline PSMM (\%) & $42.20 \pm 4.53$ & 29.38 & 52.33 & 10.7 \\
\hline PPM (\%) & $14.87 \pm 1.51$ & 10.49 & 18.24 & 10.1 \\
\hline \hline
\end{tabular}




\begin{tabular}{|c|c|c|c|c|}
\hline VFA $/ \mathrm{kg}\left(\mathrm{cm}^{2} / \mathrm{kg}\right)$ & $1.31 \pm 0.36$ & 0.48 & 2.42 & 27.3 \\
\hline BFMI $\left(\mathrm{kg} / \mathrm{m}^{2}\right)$ & $6.95 \pm 2.75$ & 1.89 & 17.77 & 39.6 \\
\hline SMMI $\left(\mathrm{kg} / \mathrm{m}^{2}\right)$ & $11.19 \pm 1.25$ & 8.26 & 15.65 & 11.2 \\
\hline PMI $\left(\mathrm{kg} / \mathrm{m}^{2}\right)$ & $3.94 \pm 0.41$ & 2.94 & 5.41 & 10.3 \\
\hline FFMI $\left(\mathrm{kg} / \mathrm{m}^{2}\right)$ & $19.80 \pm 1.98$ & 14.85 & 27.31 & 10.0 \\
\hline VFAI $\left(\mathrm{cm}^{2} / \mathrm{m}^{2}\right)$ & $0.36 \pm 0.12$ & 0.13 & 0.74 & 34.8 \\
\hline PFI (kg) & $0.67 \pm 0.31$ & 0.22 & 1.93 & 46.5 \\
\hline IH $\left(\% /\left(\mathrm{kg} / \mathrm{m}^{2}\right)\right)$ & $0.94 \pm 0.21$ & 0.40 & 1.49 & 22.7 \\
\hline
\end{tabular}

Results for factorial analysis of variance are shown in Tables 2-4. $\mathrm{KMO}$ and Bartlett's test showed very good sampling adequacy of 0.661 with significance lower than 0.001. Principal component analysis showed high cumulative values (Table 2). It means that the proportion of variance of each variable that can be explained by factor is very high. It might be the evidence that the chosen index values are good representatives of the heightindependent and volume-independent indicators of the body composition. 
Table 2_Principal component analysis.

\begin{tabular}{|c|c|c|}
\hline \multicolumn{3}{|c|}{ Communalities } \\
\hline VARIABLES & Initial & Extraction \\
\hline PBF (\%) & 1.000 & .990 \\
\hline PSMM & 1.000 & .943 \\
\hline PPM & 1.000 & .990 \\
\hline VFA/kg $\left(\mathrm{kg} / \mathrm{cm}^{2}\right)$ & 1.000 & .994 \\
\hline BFMI $\left(\mathrm{kg} / \mathbf{m}^{2}\right)$ & 1.000 & .957 \\
\hline SMMI $\left(\mathrm{kg} / \mathrm{m}^{2}\right)$ & 1.000 & .957 \\
\hline PMI $\left(\mathrm{kg} / \mathrm{m}^{2}\right)$ & 1.000 & .988 \\
\hline FFMI $\left(\mathrm{kg} / \mathrm{m}^{2}\right)$ & 1.000 & .987 \\
\hline VFAI & 1.000 & .994 \\
\hline PFI (kg) & 1.000 & .898 \\
\hline IH & 1.000 & .974 \\
\hline
\end{tabular}

Table 3 shows loading for every factor and defines the three most important factors that explain $97.004 \%$ of total variance which leaves $2.996 \%$ of variance to error of measurement. In other words, measurement was very precise while choice of variables was good which consequently led to high variance explanation and this could be indication of the internal validity but also the validity of the used approach.

Table 3_Loadings of every component that shows 3 independent factors.

\begin{tabular}{|c|c|c|c|c|c|c|c|}
\hline 3 & 1.246 & 11.329 & 97.004 & 1.246 & 11.329 & 97.004 & Retation \\
\hline \multirow{2}{*}{ Component } & \multicolumn{3}{|c|}{ Initial Eigenvalues } & \multicolumn{3}{|c|}{$\begin{array}{l}\text { Extraction Sums of Squared } \\
\text { Loadings }\end{array}$} & $\begin{array}{l}\text { Sums of } \\
\text { Squared }\end{array}$ \\
\hline & Total & $\begin{array}{c}\% \text { of } \\
\text { Variance }\end{array}$ & $\begin{array}{c}\text { Cumulative } \\
\%\end{array}$ & Total & $\begin{array}{c}\% \text { of } \\
\text { Variance }\end{array}$ & $\begin{array}{c}\text { Cumulative } \\
\%\end{array}$ & Total \\
\hline 1 & 5.984 & 54.398 & 54.398 & 5.984 & 54.398 & 54.398 & 5.873 \\
\hline 2 & 3.440 & 31.277 & 85.675 & 3.440 & 31.277 & 85.675 & 3.393 \\
\hline
\end{tabular}


Structure of every factor after Oblimin rotation can be seen in Table 4. Highlighted values make the structure of each factor.

Table 4_Three factors and their structure

\begin{tabular}{|c|c|c|c|}
\hline \multirow{2}{*}{ VARIABLES } & \multicolumn{3}{|c|}{ FACTORS } \\
\hline & 1 & 2 & 3 \\
\hline PPM (\%) & -.995 & .125 & -.345 \\
\hline PBF (\%) & .995 & -.092 & .356 \\
\hline PSMM (\%) & -.969 & .176 & -.306 \\
\hline PFI (kg) & -.947 & .075 & -.308 \\
\hline BFMI $\left(\mathrm{kg} / \mathrm{m}^{2}\right)$ & .946 & .132 & .428 \\
\hline IH (index unit) & .909 & -.487 & .180 \\
\hline PMI (kg/m²) & -.120 & .994 & .227 \\
\hline FFMI $\left(\mathrm{kg} / \mathrm{m}^{2}\right)$ & -.103 & .993 & .232 \\
\hline SMMI $\left(\mathrm{kg} / \mathrm{m}^{2}\right)$ & -.141 & .978 & .232 \\
\hline VFA $/ \mathrm{kg}\left(\mathrm{cm}^{2} / \mathrm{kg}\right)$ & .264 & .147 & .989 \\
\hline VFAI $\left(\mathrm{cm}^{2} / \mathrm{m}^{2}\right)$ & .473 & .353 & .969 \\
\hline
\end{tabular}

\section{Discussion}

As it is shown in Table 4, there are three (3) independent factors and according to their structure it could be concluded that all 3 factors have different biological meaning.

Structure of Factor I consists of six (6) variables that explain $54.398 \%$ of variance. Variables PBF, BFMI and IH have a strong positive correlation while PPM, PSMM, and PFI have a strong negative correlation direction. This means that if the first three mentioned variables are increased, the latter three will decrease. This is logical sequence of events because PBF, 
BFMI and IH are the measure of the size and volume independent fatness of the body while PPM, PSMM and PFI are the size and volume independent measure of the body muscularity. By making fat and muscle tissue size and volume independent, Factor I gets more biological meaning. The importance of it lies in the better understanding of the origin and nature of the relationship and interaction among different compartments (Wang et al., 2000; Wang et al., 1992; Ellis, 2000). When the structure of the body composition is observed on the molecular level, five (5) components can be seen: water, lipids, glycogen, proteins and minerals (Wang et al., 1992). In that regard, all food that humans consume contains those components in some proportion and logically if the proportion and consumed amount is not balanced the relation between components in the body might be changed (La Despres and Lamarche, 1993). This imbalance between components along with different levels of physical activity and age mainly lead either to increase of fat mass and decrease of muscle mass or increase of muscle mass followed with decrease of fat mass (La Despres and Lamarche, 1993; Hughes et al., 2002; Rakic et al., 2013; Kukic and Dopsaj, 2016; Boyce et al., 2008). Social and environmental studies have shown that in developing as well as in developed countries the prevalence of obesity is very high and continually getting higher mostly because of the sedentary lifestyle (Andersen et al., 1998; Ng et al., 2011; Ng et al., 2014; Musaiger et al., 2003; Kerkadi et al., 2005).

It has been observed that police workforce around the world show increased levels of obesity (Sorensen et al., 2000; Violanti et al., 2006; AbuAisha et al., 2008; Gu et al., 2012; Kukic and Dopsaj, 2016). Volanti et al. (2006) reported higher prevalence of obesity (BMI=29.8 \pm 5.8$)$ among police officers then regular population but they also explained this discrepancy in possibility that higher BMI in police is due to increased muscle mass. This is additional reason why this study uses indexes to avoid misleading of body composition indicators. Abu-Aisha et al. (2008) showed prevalence of overweight and obese of $49.2 \%$ in Khartoum police with BMI grater then 25 $\mathrm{kg} / \mathrm{m}^{2}$. In the study of $\mathrm{Gu}$ et al. (2012) prevalence of obesity (BMI $\geq 30$ $\mathrm{kg} / \mathrm{m}^{2}$ ) was $48.3 \%$ among male police officers. They also showed that PBF was less strongly correlated with BMI, waist circumference, and abdominal fat which could be evidence for using new IH index. Kukic and Dopsaj (2016) reported prevalence of overweight police officers $\left(\mathrm{BMI} \geq 25 \mathrm{~kg} / \mathrm{m}^{2}\right)$ in 
Abu Dhabi to be $71.18 \%$. This is a good reason for the study to try to answer the question why prevalence is so high. In an extensive longitudinal study Sorensen et al. (2000) showed that time of 12 years spent in service led to increase of obesity among Finnish police officers which was related to decreased energy expenditure during leisure physical activity. They explained this with increased number of cars for 40\% between 1982 and 1992, 40-min increase in television watching and increase in house appliances and games and videos.

Musaiger and Bener (2003) showed that among male university students prevalence of obesity was $35.7 \%$ and that the risk of obesity was greater in those who spent more hours watching television $(\mathrm{RR}=1.31)$ and in those who were not practicing sport $(\mathrm{RR}=1.77)$. Only $8.4 \%$ of obese and $17.1 \%$ of non-obese students were reported to participate in some physical activity which most likely was the main reason for high obesity prevalence. Anderson et al. (1998) also reported that lack of physical activity and increased time spent next to the TV, playing games and personal computer increased prevalence of overweight children in America. Next to the physical activity, nutrition habits have significant influence on the body composition status. Studies have shown increased caloric intake due to snacks and caloric beverages in the Emirati population, especially during the time spent watching TV (Ng et al. 2011; Kerkadi et al. 2005).

It could be concluded that the level of physical activity and dietary habits are a very strong link between body size and volume independent fat and muscle components. Physical inactivity leads to excess storage of the unutilized energy in form of fat tissue. On the contrary, increased physical activity results in muscle tissue development. Furthermore, there is a huge environmental influence on the level of physical activity and eating habits. Accordingly, Factor I should be named as a PHYSICAL INACTIVITY AND NUTRITION factor.

Factor II explaines $31.277 \%$ of variance and its structure comprises three (3) variables: PMI, FFMI, and SMMI where all three have high correlation values $-0.994,0.993$ and 0.978 . This favors high internal validity and it might indicate high external validity. In other words, chosen variables do explain the same phenomenon which is defined as a factor in terms of 
factorial analysis. On tissue level, FFMI and SMMI are body size independent representatives of fat-free mass (FFM) or more precisely skeletal muscle mass while PMI indicates body volume independent protein structure which gives better insight in molecular level of the body (Wang et al., 2000; Wang et al., 1992; Ellis, 2000). Moreover, PMI has the highest correlation value and it is probably due to the nature and role of proteins in human tissue. Proteins and minerals make density of FFM and protein synthesis is an essential and necessary process for muscle growth and maintenance (Witard et al., 2016; Fuller et al., 1992; Stankovic et al., 2013; Aleman-Mateo et al., 2014). Practically, increased protein synthesis will lead to muscle growth and with it increased fat-free mass density. The best natural way for increased protein synthesis is through various physical activities and exercise programs, especially exercise with external load/weigh or resistance exercise (Ross et al. 1996; Frontera et al. 1988; Stankovic et al., 2013, Wernbom et al., 2007, Rakic et al., 2013). In study of Ross et al. (1996) reduction of subcutaneous and visceral fat tissue has occurred along with increase of strength and muscle size and it happened in both groups - aerobic training and diet and resistance training and diet. Frontera et al. (1988) showed increase of 10-11\% in muscle area after 12 week of strength training in older men and in the same study they also showed significant increase in strength of 5\% per training day. In an extensive review study Wernbom et al. (2007) showed influence of frequency, intensity, volume, and mode of strength training on whole muscle cross-sectional area. Developing and maintaining skeletal muscle mass have a huge role in humans. Mobility, muscle strength, stamina and balance all depend on quality and density of SMM (Janssen et al., 2002). It has the most important role in the quality and quantity of the movement in humans. Those are general health standards as well as general job requirements for the police officers (Spitler et al., 1987; Janssen et al., 2002; Rakic et al., 2013). Biological significance of PMI, FFMI and SMMI is undoubtable because of many other positive impacts of FFM on the body health status such as better basal metabolic rate, better quality of body posture, improved blood flow, increased movement potential, etc. Furthermore, the amount of skeletal muscle mass is gender and age dependent and loss of muscle density brings negative effects on health and quality of life (Janssen et al., 2002; Janssen et al., 2000; Seino et al., 2015).

Gathered and analyzed information mentioned above are clear evidence that PMI, FFM and SMMI are true representatives of skeletal muscle and its density. Thus, their role in body composition is important 
because of the necessity of the skeletal muscles in everyday life. Quality of fat-free mass is a precondition for good body composition and it can be built and maintained naturally only through physically active life or planned exercise programs. Accordingly, Factor II should be named as a PHYSICAL ACTIVITY AND EXERCISE factor.

Factor III explains the final $11.329 \%$ of the total variance. Structurally, Factor III consists of 2 index variables. The first one is the body volume-independent visceral fat area index - VFA/ $\mathrm{kg}$ and the second one is the body size-independent visceral fat area index - VFAI. Practically, these indexes should define a person's degree of visceral fatness no matter how tall that person is or what body weight the person has. The lower the index the visceral fat area is smaller. Although Factor I depends mainly on body fats, factorial analysis showed that certain positioning of the body fats plays significant role in body morphology (Nguyen-Duy et al., 2003; Banerji et al., 1999; Kuk et al., 2006; La Despres and Lamarche, 1993). Nguyen-Duy et al. (2003) showed that visceral fat has a primary role in lipid-related metabolic risk but they also found that fatty liver correlated with metabolic risk. Fatty liver partially could be explained with constantly increased flux of free fat acids due to increased abdominal adiposity. Banerji et al. (1999) on a sample of Asian Indian men found that visceral adipose tissue is associated with insulin resistance hyperinsulinemia, and dyslipidemia and may be responsible for increased cardiovascular disease and diabetes. Kuk et al. (2006) found VFA to be independent predictor of all-cause mortality in men after they adjusted VFA for the other fat measures. This directly proves approach of body volume and size independent indexes and, to some extent, explains why VFA related indexes are an independent factor of the body composition structure. In their extensive literature review La Despres and Lamarche (1993) explained influence of abdominal adiposity on lipoprotein level. They reported that lipoprotein best correlates to risk of cardio-vascular diseases. Furthermore, they explained that adipose tissue and hypertension with abdominal obesity and insulin-resistance related to it might indicate elevated blood pressure better than body fatness per se. According to the same review visceral fats are sometimes responsible for metabolic complications. Altered sex steroid profile is probably the result of the joined effects of abdominal obesity, insulin resistance, and dyslipidemia. 
Visceral adiposity has a considerable role in health risk. Increased visceral fatness correlates with several health-related risk factors (obesity, hypertension, hyperglycemia, and dyslipidemia) that joined together constitute condition called metabolic syndrome (Nguyen-Duy et al., 2003; Banerji et al., 1999; Kuk et al., 2006; La Despres and Lamarche, 1993, Wannamethee et al., 2005; Ardern et al., 2003). Factor III might be called a risk factor but we should bear in mind that origin of this risk factor lies in a sedentary lifestyle. It was shown in Factor I that hours spent watching TV and hypokinezia correlate with increased obesity. The structure of Factor II shows that physical activity and exercise are dominantly responsible for components in Factor II. When we go back to Table 4, VFAI is weakly saturated on Factor I (0.473) and Factor II (0.353). Interestingly, saturation within PHYSICAL ACTIVITY AND EXERCISE factor is not negative. Thus, the conclusion could be made that sedentary life affects visceral adipose tissue independently of physical activity (La Despres and Lamarche, 1993; Ng et al., 2011; Kerkadi et al., 2009). In that regard, Factor III should be named a SEDENTARY LIFESTYLE factor.

\section{Conclusion}

This study was conducted with an aim to determine the factorial structure of the body composition in Abu Dhabi Police personnel. The results were obtained from the sample of 120 employees of Abu Dhabi police. The study found that three (3) independent factors influence body composition: Factor I - PHYSICAL INACTIVITY AND NUTRITION, Factor II PHYSICAL ACTIVITY AND EXERCISE, and Factor III - SEDENTARY LIFESTYLE.

Factor I comprises 6 variables: 3 that correlate positively (PBF, BFMI, and $\mathrm{IH})$ - representatives of body fatness and 3 that correlate negatively (PPM, PSMM, and PFI) - representatives of body muscularity. PBF, BFMI and IH have higher correlation values than PPM, PSMM, and PFI which most likely might be the result of physical inactivity and bad eating habits.

Factor II consists of 3 variables - PMI, FFMI, and SMMI. All three variables explain fat-free mass independently of body size. Practically, these 
indexes give biological meaning to fat-free tissues. SMM is directly dependent on PM, while FFM is mostly built of SMM. Accordingly, these indexes could be more accurate when speculating about the tissue quality no matter what race, age or gender somebody is.

Factor III consists of 2 variables: VFA/kg and VFAI. These variables represent visceral fat area independently of body mass (VFA $/ \mathrm{kg}$ ) and body size (VFAI). Thus, it would probably increase biological accuracy if presenting visceral adiposity through independent indexes.

This research showed considerable evidence of validity of the chosen method. However, further research is needed to investigate sensitivity, reliability and validity of this approach. For some huge systems, as the Police or Military systems, it might be very useful to define the factors that have impact on the structure of the body morphology. The knowledge about the cause of this phenomenon is a precondition for developing the system that would be able to resist and/or suppress unfavorable trends.

\section{Limitations}

The sample of this study included only male employees so the results are applicable only on male population of Abu Dhabi police. Furthermore, the sample size could include more participants. Measurement procedures were conducted during the day because not all participants were able to come in the morning. Also, we could not control food and liquid intake before measurement but we did request the participants to fast 3 hours prior testing. Climate conditions in the United Arab Emirates are unique so these results partly could be due to environmental conditions. Accordingly, these results are characteristic for this population and most probably could not be applied to other populations. However, the principle of this research is partly based on these differences so further research on the other populations, a wider age range and female gender is required. 


\section{Acknowledgement}

This research is part of the project Effects of applied Physical activity on locomotor, metabolic, psychosocial and educational status of the population of the Republic of Serbia, under number III47015, which is financed by Ministry of Education and Science of Republic of Serbia - Cycle of Projects 2011-2016.

\section{Reference:}

1. Abu-Aisha, H., Elhassan, E. A., Khamis, A., Abu-Elmaali, A., (2015). Hypertension and obesity in police forces households in Khartoum, Sudanese Journal of Public Health, 3(1): 17-25

2. Adler, N., Eper, E., Castellazzo, G., Ickovic, R. J., (2000). Relationship of subjective and objective social status with psychological and physiological functioning: Preliminary data in Healthy white women, Health Psychology, 19(6): 586-592.

3. Aleman-Mateo, H., Carreon, V., Macias, L., Garzia, H., Gallegos-Aguilar, A., Enriques, J., (2014). Nutrient-rich dairy proteins improve appendicular skeletal muscle mass and physical performance, and attenuate the loss of muscle strength in older men and women subjects: a single-blind randomized clinical trial, Clinical Intervention in Aging, 9: 1517-1525.

4. Andersen, R. E., Crespo, C. J., Bartlett, S. J., Cheskin, L. J., Pratt, M., (1998). Relationship of physical activity and television watching with body weight and level of fatness among children: results from the Third National Health and Nutrition Examination Survey, Jama, 279(12): 938-942.

5. Ardern, C. I., Katzmarzyk, P. T., Janssen, I., Ross, R., (2003). Discrimination of health risk by combined body mass index and waist circumference, Obesity Research, 11(1): 135-142.

6. Banerji, M. A., Faridi, N., Atluri, R., Chaiken, R. L., Lebovitz, H. E., (1999). Body Composition, Visceral Fat, Leptin, and Insulin Resistance in Asian Indian Men, The Journal of Clinical Endocrinology \& Metabolism, 84(1): 137-144.

7. Bogin, B., Rios, L., (2003). Rapid morphological change in living humans: implications for modern human origins, Comparative Biochemistry and Physiology Part A: Molecular \& Integrative Physiology, 136(1): 71-84. 
8. Boyce R.W., Jones G.R., Lloyd C.L., Boone E.L., (2008). A longitudinal observation of police: body composition changes over 12 years with gender and race comparisons, Journal of Exercise Physiology, 11(6): 1-13.

9. Cardel, M. I., Johnson, S. L., Beck, J., Dhurandhar, E., Keita, A. D., Tomczik, A. C., Pavela, G., Huo, T., Janicke, D.M., Muller, K., Piff, P.K., Peters, J.C., Hill, J.O., Allison, D.B., (2016). The effects of experimentally manipulated social status on acute eating behavior: A randomized, crossover pilot study, Physiology \& Behavior, 162: 93-101.

10. Dimitrijević, R., Umičević D., Dopsaj, M., (2013). Mofološki model ženskih pripadnika komunalne policije Beograda, Journal of the Anthropological Society of Serbia, 48: 97-106.

11. Djordjevic-Nikic, M., Dopsaj, M., Rakic, S., Subosic, D., Prebeg, G., Macura, M., Mladjan, D., Kekic, D., (2013). Morphological model of the population of working-age women in Belgrade measured using electrical multichannel bioimpedance model: pilot study, Physical Culture, 67(2): 103-112.

12. Dopsaj, M., Dimitrijevic, R., (2013). The Academy of Criminalistics and Police studies female studies morphological status defined by multichannel bioelectrical impedance, NBP: Journal of Criminalistics and Law, 18(1): 39-56

13. Ellis, K., (2000). Human Body Composition: In Vivo methods, Physiological Reviews, 80(2): 650-671.

14. Frontera, W. R., Meredith, C. N., O'Reilly, K. P., Knuttgen, H. G., Evans, W. J., (1988). Strength conditioning in older men: skeletal muscle hypertrophy and improved function, Journal of Applied Physiology, 64(3): 1038-1044.

15. Fuller, N. J., Jebb, S. A., Laskey, M. A., Coward, W. A., Elia, M., (1992). Four-component model for the assessment of body composition in humans: comparison with alternative methods, and evaluation of the density and hydration of fat-free mass, Clinical Science, 82(6) 687-693.

16. Gu, M. J. K., Charles, L. E., Burchfiel, C. M., Fekedulegn, D., Sarkisian, M. K., Andrew, M. E., Ma, C., Violanti, J. M., (2012). Long work hours and adiposity among police officers in a US Northeast City, Journal of Occupational and Environmental Medicine, 54(11): 1374-1381.

17. Hughes, V. A., Frontera, W. R., Roubenoff, R., Evans, W. J., Singh, M. A. F., (2002). Longitudinal changes in body composition in older men and women: role of body weight change and physical activity, The American Journal of Clinical Nutrition, 76(2): 473-481. 
18. Janssen, I., Heymsfield, S. B., Ross, R., (2002). Low relative skeletal muscle mass (sarcopenia) in older persons is associated with functional impairment and physical disability, Journal of the American Geriatrics Society, 50(5): 889-896.

19. Janssen, I., Heymsfield, S. B., Wang, Z., Ross, R., (2000). Skeletal muscle mass and distribution in 468 men and women aged 18-88 yr, Journal of Applied Physiology, 89(1): 81-88.

20. Kasabova, B. E., Holliday, T. W., (2015). New model for estimating the relationship between surface area and volume in the human body using skeletal remains, American Journal of Physical Anthropology, 156(4): 614-624.

21. Katzmarzyk, P. T., Leonard, W. R., (1998). Climatic influences on human body size and proportions: ecological adaptations and secular trends, American Journal of Physical Anthropology, 106(4): 483-503.

22. Kerkadi, A., Abo-Elnaga, N., Ibrahim, W., (2005). Prevalence of overweight and associated risk factors among primary female school children in Al-Ain city United Arab Emirates, Emirates Journal of Agricultural Sciences, 17(1): 43-56.

23. Kuk, J. L., Katzmarzyk, P. T., Nichaman, M. Z., Church, T. S., Blair, S. N., Ross, R., (2006). Visceral fat is an independent predictor of all-cause mortality in men, Obesity, 14(2): 336-341.

24. Kukic, F., Dopsaj, M., (2016). Structural analysis of body composition status in Abu Dhabi police personnel", NBP: Journal of Criminalistics and Law, 21(3): 19-38

25. Kyle, U. G., Schutz, Y., Dupertuis, Y. M., Pichard, C. (2003). Body composition interpretation: contributions of the fat-free mass index and the body fat mass index, Nutrition, 19(7): 597-604.

26. Després, J. P., Lamarche, B., (1993). Effects of Diet and Physical Activity on Adiposity and Body Fat Distribution: Implications for the Prevention of Cardiovascular Disease, Nutrition Research Reviews, 6(1): 137-159.

27. Musaiger, A. O., Lloyd, O. L., Al-Neyadi, S. M., Bener, A. B., (2003). Lifestyle factors associated with obesity among male university students in the United Arab Emirates, Nutrition \& Food Science, 33(4): 145-147.

28. Ng, M., Fleming, T., Robinson, M., Thomson, B., Graetz, N., Margono, C., et al., (2014). Global, regional, and national prevalence of overweight and obesity in children and adults during 1980-2013: a systematic analysis for the Global Burden of Disease Study 2013, The Lancet, 384(9945): 766-781. 
29. Ng, S. W., Zaghloul, S., Ali, H. I., Harrison, G., Popkin, B. M., (2011). The prevalence and trends of overweight, obesity and nutrition-related non-communicable diseases in the Arabian Gulf States, Obesity Reviews, 12(1): 1-13.

30. Ng, S. W., Zaghloul, S., Ali, H., Harrison, G., Yeatts, K., El Sadig, M., Popkin, B. M. (2011). Nutrition transition in the United Arab Emirates, European Journal of Clinical Nutrition, 65(12): 1328-1337.

31. Nguyen-Duy, T. B., Nichaman, M. Z., Church, T. S., Blair, S. N., Ross, R., (2003). Visceral fat and liver fat are independent predictors of metabolic risk factors in men, American Journal of PhysiologyEndocrinology and Metabolism, 284(6): 1065-1071.

32. Rakić, S., Marković, M., Dopsaj, M., Mlađan D., Subošić, D., (2013). Initial model of Men's muscle structure indicators defined by the method of Multichannel Bioelectrical Impedance, Facta Universitatis, Series: Physical Education and Sport, 11(1): 23-33.

33. Ross, R., Rissanen, J., Pedwell, H., Clifford, J., Shragge, P., (1996). Influence of diet and exercise on skeletal muscle and visceral adipose tissue in men, Journal of Applied Physiology, 81(6): 2445-2455.

34. Ruff, C. B., (2000). Body size, body shape, and long bone strength in modern humans, Journal of Human Evolution, 38(2): 269-290.

35. Seino, S., Shinkai, S., Iijima, K., Obuchi, S., Fujiwara, Y., Yoshida H., et al., (2015). Reference Values and Age Differences in Body Composition of Community-Dwelling Older Japanese Men and Women: A Pooled Analysis of Four Cohort Studies, Public Library of Science One, 10(7): 115.

36. Sorensen, L., Smolander, J., Louhevaara, V., Korhonen, O., Oja, P. (2000), Physical activity, fitness and body composition of Finnish police officers: a 15-year follow-up study, Occuptional Medicine, 50(1): 2-10.

37. Spitler, D. L., Jones, G., Hawkins, J., Dudka, L., (1987). Body composition and physiological characteristics of law enforcement officers, British Journal of Sports Medicine, 21(4): 154-157.

38. Stankovic, A., Djordjevic-Nikic, M., Kukic, F., Petrovic, M., Cvijanovic, N., Todorovic, N., (2013). The offect of strength training on the testosterone level in men, Physical Culture, 67(2): 157-177.

39. Stock, J. T., (2006). Hunter-gatherer postcranial robusticity relative to patterns of mobility, climatic adaptation, and selection for tissue economy, American Journal of Physical Anthropology, 131(2): 194-204.

40. Violanti, J. M., Burchfiel, C. M., Miller, D. B., Andrew, M. E., Dorn, J., Wactawski-Wende, J., Beighley, C. M, Pierino, K., Joseph, P. N., Vena, J. E., Sharp, D. S., Trevisan, M., (2006). The buffalo cardio-metabolic 
occupational police stress (BCOPS) pilot study: methods and participant characteristics, Annals of Epidemiology, 16(2): 148-156.

41. Vuckovic, G., Subosic, D., Kekic, D., (2011). Physical abilities of police officers as prerequisite for suppressing violence at sporting events in the Republic of Serbia, Facta Universitatis, Series: Physical Education and Sport, 9(4): 385-397.

42. Wang, Z. M., Pierson, R. N., Heymsfield, S. B., (1992). The five-level model: a new approach to organizing body-composition research, The American Journal of Clinical Nutrition, 56(1): 19-28.

43. Wang, Z., Deurenberg, P., Heymsfield, S. B., (2000). Cellular-Level body composition model: a new approach to studying fat-free mass hydration, Annals of the New York Academy of Sciences, 904(1): 306-311.

44. Wang, Z., St-Onge, M. P., Lecumberri, B., Pi-Sunyer, F. X., Heshka, S., Wang, J., Kotler, D. P., Gallagher, D., Wielopolski, L., Pierson, R. N Jr., Heymsfield, S. B., (2004). Body cell mass: model development and validation at the cellular level of body composition, American Journal of Physiology-Endocrinology and Metabolism, 286(1): 123-128.

45. Wannamethee, S. G., Shaper, A. G., Morris, R. W., Whincup, P. H., (2005). Measures of adiposity in the identification of metabolic abnormalities in elderly men, The American Journal of Clinical Nutrition, 81(6): 1313-1321.

46. Weaver, T. D., Steudel-Numbers, K., (2005). Does climate or mobility explain the differences in body proportions between Neanderthals and their Upper Paleolithic successors?, Evolutionary Anthropology: Issues, News, and Reviews, 14(6): 218-223.

47. Wernbom, M., Augustsson, J., Thomeé, R., (2007). The influence of frequency, intensity, volume and mode of strength training on whole muscle cross-sectional area in humans, Sports Medicine, 37(3): 225-264.

48. Witard, O. C., Wardle, S. L., Macnaughton, L. S., Hodgson, A. B., Tipton, K. D. (2016). Protein considerations for optimizing skeletal muscle mass in healthy young and older adults, Nutrients, 8(4): 181. 


\section{Факторска анализа телесног састава међу полицајцима у Абу Дабију}

Апстракт: Циљ ове студије био је да дефинише факторе који утичу на телесну композииију запослених у полииији Абу Дабија. Телесна композииија 120 насумично изабраних мушких полищајача различитог узраста измерена је током Октобра и Новембра 2016-те године у секиији за спортске активности Абу Даби полищије.

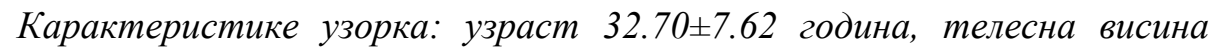
(BH) $173.54 \pm 6.24 \mathrm{~cm}$, телесна тежина (BW) $80.55 \pm 11.36 \mathrm{~kg}$, и индекс телесне масе (ВМI) $26.76 \pm 3.60 \mathrm{~kg} / \mathrm{m} 2$. Једанаест варијабли статистички је евалуирано употребом факторске анализе варијансе: проченат телесних масти (PBF), проценат скелетних мишића (SMM), проченат протеинске масе (РPM), независна површина висиералних масти (VFA/kg), индекс телесних масти (BFMI), индекс телесних мишића (SMMI), индекс протеинске масе (PMI), индекс безмасне масе (FFMI), индекс површине висиералних масти (VFAI), протеинско-масни индекс (PFI), и индекс хипокинезије (IH). КМО и Бартлетов тест показали су веома добру адекватност узорковања од 0.661 на нивоу поузданости испод 0.001. Анализа основних компоненти показала је високе кумулативне вредности, што иде у прилог валидности изабраних варијабли. Издвојила су се 3 главна фактора која заједно објашьавају 97.004\% укупне варијансе: I - неактивност и исхрана, II - физичка активност и вежбање, и III - седенторни начин живота. У сврхе праћена нивоа неактивности, заједно са навикама у исхрани, потребно је пратити 2 индексна показатеља - РРМ и РВF; у сврху праћења квантитета физичких активности и квалитета тренажних програма - PMI и FFMI; за праћење утицаја животног стила могу се пратити индекси VFA/kg u VFAI.

Кључне речи: вежбе, неактивност, статичност, животни стил, здравље. 